\title{
On the Longevity of Seeds of Nelumbo nucifera.
}

\author{
By \\ Ichiro Ohga,
Government Botanist of Kwantung Leased Territory and Professor of
Botany, Educational Institute, South Manchuria
Railway Co., Dairen. \\ With 7 Text-Figures.
}

\section{INTRODUCTION.}

Works such as those of BeCQuerel (1907) and EwArt (1908) on the longevity of seeds are well known. According to Ewart's own observations, of 12 seeds of Hovea heterophylla which were 105 years old, two seeds germinated. After consideration upon the longevity of the seeds of some 2500 kinds of plants, he states, however, that " the probable extreme duration of vitality for any known seeds may be set between 150 and 250 years (Leguminosæ)." And also "Probably the maximal duration for Malvaceae and Nymphaeaceae lies between 50 ard 150 years......" EwART's statements were chiefly based upon the experiments made with seeds kept in dry air for a varying number of years. He added also that the impermeable seeds will preserve their vitality longer in the soil than in the air. Of some 500 kinds of seeds, 25 to 135 years old, used in BeCQuerel's experiments, there were no seeds that lived more than 86 years in the air. My germination experiments with the seeds of Nelumbo nucifera, discovered from the soil of a district in South Manchuria, have, however, shown that the Nelumbo seeds have a longevity of at least 120 years or more; and 35 seeds used in my own experiments germinated without exception and about 15 seeds sent to other persons have invariably germinated according to information received.

This Manchurian Nelumbo became known to me for the first time, a few years ago, through a number of seeds given me by Dr. C. K.IDo, 
Chief Geologist of the South Manchuria Railway Co.. Recently I have visited the district where those seeds were found in order to study the -topographical conditions of the locality, ascertain the occurrence of the seeds and secure a number of the buried seeds.

According to Prof. M. MryoshI, he received a few seeds of this Nelumbo from Dr. N. Fukuchi ten years ago and the germination experiments carried out with them by Dr. Y. KORIBA showed that they were alive. As I am unaware of any report having been published so far bearing upon germination experiments with Manchurian Nelumbo, I considered that the publication of a short note on the results of my own germination experiments may not be superfluous.

\section{Topography of the Seed-bearing Land.}

Towards the north end of the Kwantung Leased Territory, South Manchuria, there is situated the village of Pulantien on the west coast

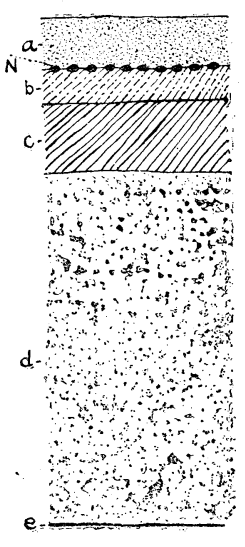

Fig. 1. Schematic section of Seed-bearing land

a. Upper loess layer $1 / 2-2 / 3 \mathrm{~m}$

b. Peat layer $1 / 3-1 / 2 \mathrm{~m}$.

c. Mud layer $2 / 3-1 \mathrm{~m}$.

d. Lower thick loess layer $11 \mathrm{~m}$.

e. Water level of Pulantien River.

$N$. Nelumbo seeds. of the territory: and within about one Kilometre from Pulantien along the road leading to Pitsuwo on the east coast, there lies the village of Liu-chia-tung. The plain lying to the north of the latter village is the district where the buried seeds of Nelumbo occur. The plain is a large basin, extending about two miles and a half in length as well as in width, surrounded by hills of fifty to a hundred metres high. Along the eastern side of the western h.lls runs the South Manchuria Railway line north and south; along the west side of the eastern hills runs the road to Pitsuwo; and Lui-chia-tung is situated at the foot of the southern h:11s.

The rocks forming the surrounding hills are of Mesozoic origin, and the basin consists of the loess formed by the accumulation of dust of the Gobi desert, which took place since the Quarternary. The loess nature of the soil of the basin being indicated by the existence of loesschild. Across the mididle of 
the basin in the direction north-west to south-east runs the Pulantien River. Generally the water in the river is shallow, but the river bed lies about 13 metres below the level of the plain, as seen by the hight of the precipice like river banks (Figs. 1 and 4 ). This is probably the result of the errosive action of the river flowing through the loess plain. This basin is now entirely cultivated, sorghum corn, millet, wheat, etc. being grown.

Digging the loess soil which forms the fertile plain of the basin, $1 / 2$ to $2 / 3$ metres deep, a layer of peat is exposed. The latter is $1 / 3$ to $1 / 2$ metres thick. Underneath the peat is a layer of gray mud $2 / 3$ to one metres thick. Below the mud lies thick loess.

Nelumbo seeds are found in the upper most part of the peat layer. Seeds on which my observations were made were mainly discovered in the neighborhood of Lin-chia-tung. The peat is digged out for fuel by the village people during the winter season when they have no agricultural work. According to the villagers, Nelumbo seeds are said to be found every where in the basin, and are often eaten by children.

\section{Longevity of the Seeds.}

As regards the history of formation of the basin the following sequence of events may be suggested; There once existed a large lake surrounded by the hills, which now border the basin; the Pulant:en River enterd into the lake. From the lake, small streams run out and passing by the village of Pulantien poured into the Gulf of Pechili. The decay of Hydrophytes in the lake formed the peat layer described before. The loess forming the bottom of the lake was changed into mud by the action of the hydrophytic vegetation. Then, either by the heavy " rain fall during the months of July and August every year or by an uuusual heavy rain fall in some particular years, the outlet of the lake was enlarged, so that the water level of the lake was lowered until the lake became finally dry. Then the course of the present Pulantien River was established; the erosive action of the water of the river soon began to act, and finally caused the river to run 13 metres below the surface of the basin. The dust annually blown from the Gobi desert accumulated on the dried bottom of the lake and formed the deposit $1 / 2$ metre thick which forms the land of cultivation of the present date.

The village land of Liu-chia-tung and the basin is an estate of 


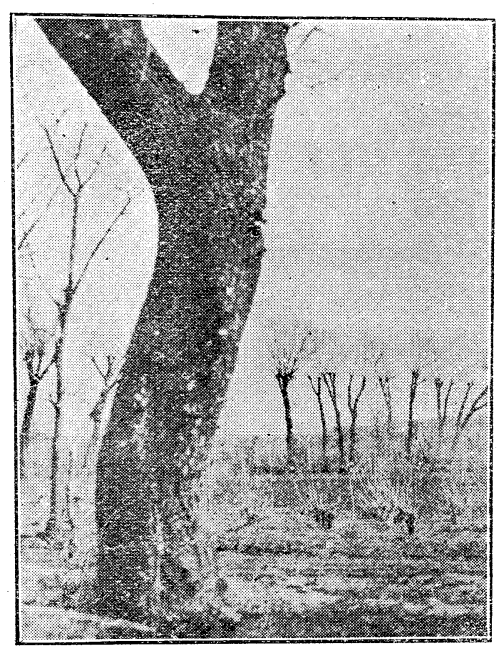

F.g. 2. A portion of basin where the Nelmbo seeds are buried, and willow-trees grow

Mr. U. Liu, the director of the Iiantung Bank in Dairen. According to his narrative, his ancestors were natives of Shan-Si Province, and having migrated to Liu-chia-tung during the Yuncheng dynasty, about two hundred years ago, cultivated the basin. Four generations passed of his famly, as is shown by the tombs of his ancestors now existing in his cemetry in the village.

Where Nelumbo seeds were found, there grow large willow trees, Salix babylonica, which are estimated to be 120 or 130 years old, judging by the diameter of the trunk (Figs. 2 and 3 ). As willow trees do not grow in water, they must have grown since the lake dried up. Consequently the lake dried up at leasi 120 or 130 years ago, when the Nelumbo seeds were already shed. On my visit of Pulantien river, kindly accompanied by $\mathrm{Mr}$. LiU

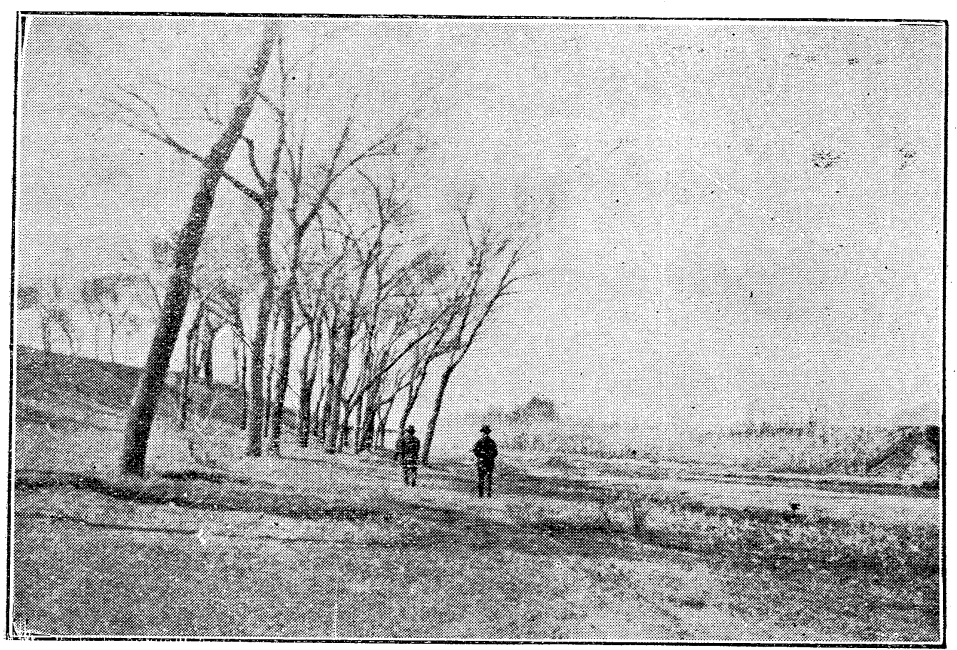

Fig. 3. A view of valley of the Pulantien River, the uppar layer of both banks containing Nelumbo seeds. 


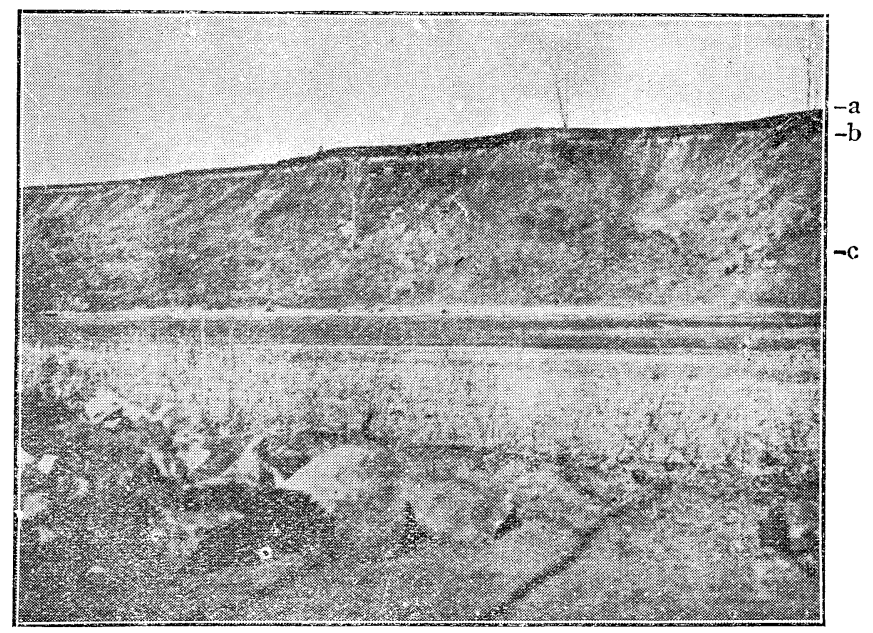

Fig. 4. A view of the precipice of the bank of Pulantien River (13 metres high). a, upper dark colored layer consists of 2 sublayers, upper loess layer and peat layer on which Nelumbo seeds lie; $b$, Mud layer; $c$, lower thick loess lyaer.

at the begining of April of this year, he pointed out a certain rock on the bank of the river, saying that the rock was not yet exposed thirty years ago. The rock in question is now nearly one metre high, so that the annual rate of the descent of the river bed is to be estimated at $3 \mathrm{~cm}$. . Consequently the total descent of 12.5 metres (deducing $50 \mathrm{~cm}$. of soil above the seeds) must have taken place by the erosive action of water for about 400 years (Figs. 3 and 4 ).

A more definite account on the rate of lowering of the river bed and on the nature of the soil above the Nelumbo seeds is reserved for a later occasion.

From the facts given above, it would be safe to put at at least $\mathbf{1 2 0}$ years the time passed since the seeds have been shed, although it is probable that the seeds have remained buried 200 years or even 400 years.

It is desirable that the germination of those seeds shall be tested hereafter in an interval of from 10 to 20 years by botanists, in order to determine the maximum longevity of Nclumbo seeds.

It is likewise desirable that the buried Nelumbo seeds shall be carefully preserved in Manchuria as a 'natural monument.' 


\section{Structure of the Seeds.}

With respect to the external features of the buried seeds, the brownish seedcoat is lighter in color than in the present day Nelumbo and has no wax on the surface; while they are quite similar to those of the present day Nelumbo in size and form. The endosperm was found to be yellowish white and the embryo green. When tasted, the

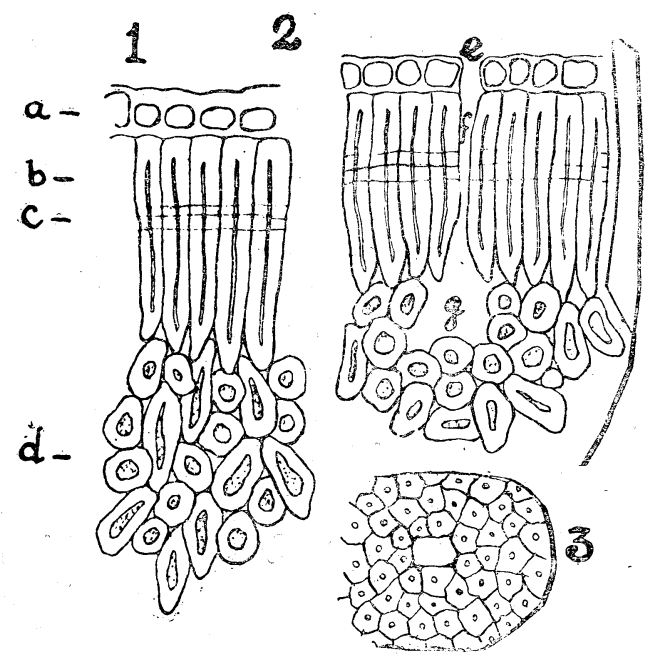

IFig. 5. Sections of seed-coat.

1. and 2. Cross-sections of sced. coat.

$a$ epidermis.

$b$, pallisade layer.

$c$, hyaline zone.

$d$, part of thick nucellar tissue.

$e$, orifice of the pore.

$f$, canal of the pore.

$g$, air chamber.

3. Surface view of the pore.

endosperm and embryo showed no difference from those of the present day seeds, the embryo having a slightly bitter taste.

Placed in water, testa, endosperm and embryo absorbed water and became swollen.

The surface of the testa has many small pores. The microscopical observation of the sections of testa showed a layer of epidermis and a layer of thick-walled pallisade cells, the cells of the latter being closely arranged with no intercellular space. Across the middle part of the pallisade layer is found a hyaline zone, which is highly refractive (Fig. 5). Treated with concentrated sulphuric acid, the pallisade layer is easily dissolved, while the hyaline zone remains undissolved even for an hour. The pallisade cells inclusive hyaline zone stain red with congored and violet with chlorzinc-iodide. The presence of byaline zone in the pallisade 
cells of the seed coat is notable in Lequminose and Nymphaeacex, both belonging to the family which is remarkable for the longevity of the seeds.

Inside the pallisade layer lies the thick nucellar layer, and in this part the intercellular spaces are large and the cell form is spherical to ellipsoidal. The cells are loosely united, and fibrovascular bundles run through the nucellar layer. In the cells of endosperm are found many small starch-grains, and in the cotyledons of the embryo, chlorophyilgrains.

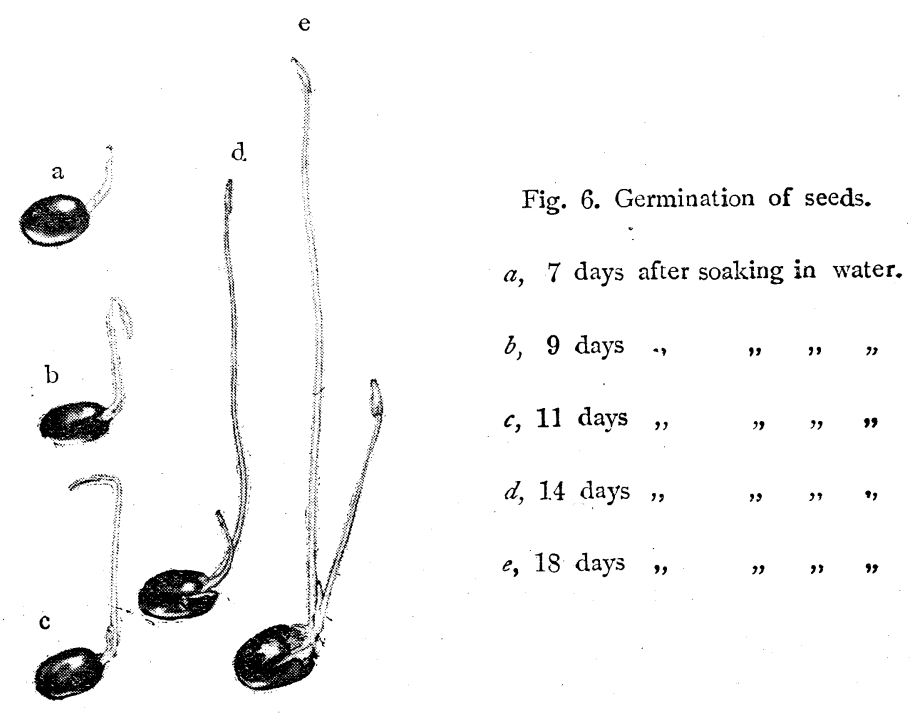

Water Containd in the Seed.

To measure the water-content of the seed, the seeds were crushed, and the testa, the endosperm and the embrys were separated from each other. Then the materials were placed in an electric oven and dried at $105^{\circ} \mathrm{C}$. for two hours. The materials were weighed before and after the drying. The water-contents were found as follows:

Testa $11.96 \%$, Endosperm $11.43 \%$, Embryo $9.93 \%$

The nearly equal percentage of water contained in both testa and endosperm is probably due to the fact that the seeds were preserved about $1 / 2-1 / 3$ metres underneath the soil for a long period. 


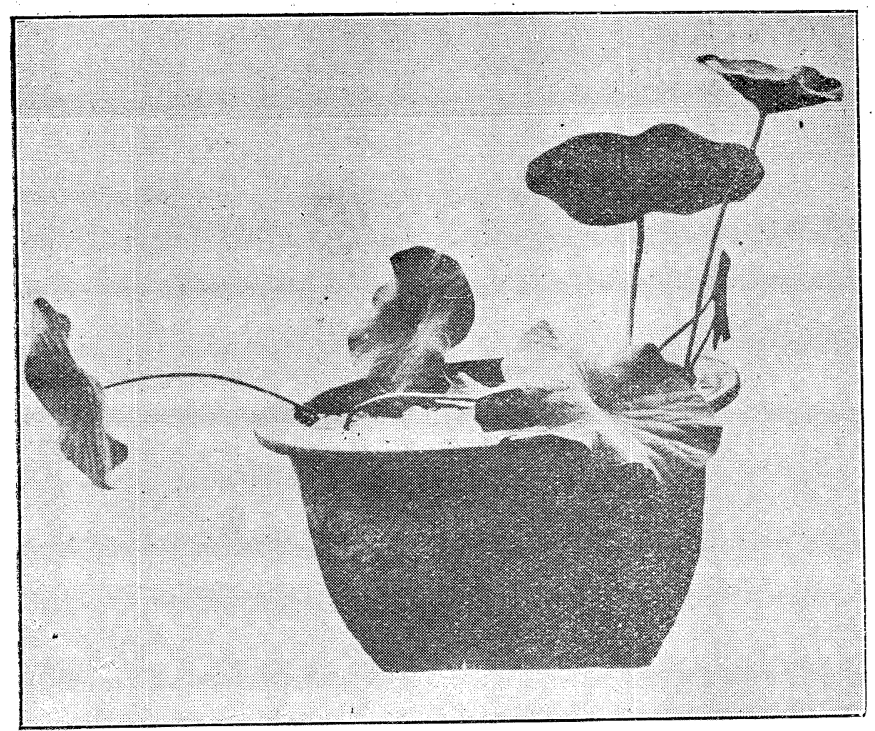

Fig. 7. Nelumbo grown four months after germination.

\section{Germination of the Seed}

A few days after digging the seeds were placed in water and left for eight months in the temperature of $15^{\circ}-20^{\circ} \mathrm{C}$. . They did rot undergo however any visible change, evidently owing to the extremely hard coat of the Nelumbo seeds. So, when one or both erds of the ellipsoidal seeds were filed till the brown nucelius tissue was exposed before soaking in water, they, without exception, absorbed water and became swollen. In about four days the embryo was seen to begin sprouting out of the seed-coat (Fig. 6); and the seedlings grew rather rapidly so that in four montls the diameter of the leaves was about $20 \mathrm{~cm}$. (Fig. 7)

\section{Summary.}

1. The longevity of Nelumbo seeds, when kept in soil, is estimated to be 120 years or more.

2. In spite of the presence of a large number of small pores in the seed-coat, the seeds did not absorb water and germinate even after eight months. 
3. The seeds, when filed before sowing, germinated without exception in a few days in spring time.

I wish to express my best thanks to Prof. K. Fujil of the Botanical z Institute, Tokyo Imperial University, for his valuable suggestions and criticism during the course of the investigation.

Dairen, July 20, 1923.

\section{Literature Cited.}

BecQuerel, P. (1907) Recherche sur la vie latente, des grains. Ann. Sci. Nat. Bot., IX. 5. Crocker, W. (1907) Germination of seeds of water plants. Bot. Gaz., XLIV.

Ernst, E. (1876) Bot. Zeit.

EWART, E. (1908) On the longevity of seeds. Proc. Roy. Soc. Victoria.

HARZ (1885) Samenkunde. 